\title{
Rumen degradability and intestinal digestibility of coconut meal
}

\author{
Javier GonZÁlez*, Santiago AndrÉs, María Remedios Alvir, \\ Carlos Alberto RodRíguEZ
}

Dpto. Producción Animal, Escuela Técnica Superior de Ingenieros Agrónomos, Universidad Politécnica de Madrid, 28040 Madrid, Spain

(Received 11 January 2001; accepted 14 May 2001)

\begin{abstract}
Effective rumen degradability (ED) and intestinal digestibility (ID) of dry matter (DM) and crude protein $(\mathrm{CP})$ of an expelling coconut meal sample were determined using in situ techniques. Degradation of coconut meal was characterised by long lag times and slow degradation rates for both DM and CP. Consequently, ED values were also low (51 and 36.5\%, respectively). Values of ID of DM were reduced with the rumen incubation time from $81.6 \%$ (original feed) to $50.3 \%$ (48 h). On the contrary, ID of CP was constant (91.3\% on average). Therefore, a content of $58 \%$ of rumen-undegraded digestible $\mathrm{CP}$ can be estimated for this sample. The apparent disagreement between the high values of both ID of CP and insoluble nitrogen in neutral detergent solution (70.5\% of total nitrogen) is discussed.
\end{abstract}

coconut meal / rumen degradability / intestinal digestibility / protein

Résumé - Dégradabilité dans le rumen et digestibilité dans l'intestin du tourteau de coprah. La dégradabilité théorique (DT) dans le rumen et la digestibilité dans l'intestin (DI) de la matière sèche (MS) et des matières azotées totales (MAT) d'un tourteau de coprah expeller ont été déterminées en utilisant des techniques in situ. La dégradation du tourteau de coprah a été caractérisée par des temps de latence très longs et des vitesses de dégradation faibles aussi bien pour la MS que pour les MAT. En conséquence, les valeurs de DT ont été faibles (51 et 36,5\%, respectivement). Les valeurs de DI pour la MS ont été diminuées avec l'augmentation du temps de séjour dans le rumen de 81,6\% (aliment de départ) à 50,3\% (48 h). En revanche, les valeurs de DI des MAT ont été stables (moyenne : $91,3 \%$ ). Le pourcentage de MAT digérées dans l'intestin de l'échantillon testé a donc été de $58 \%$. La divergence apparente entre les valeurs élevées de DI des MAT et d'azote insoluble dans une solution neutre détergente (NDF) (70,5\% de l'azote total) est discutée.

tourteau de coprah / dégradabilité ruminale / digestibilité intestinale / protéine

* Correspondence and reprints

Tel.: (34) 915493069; fax: (34) 915499763; e-mail: jgonzalez @ pan.etsia.upm.es 


\section{INTRODUCTION}

Vegetable feeds with a high proportion of protein, which bypasses the rumen and is digested in the small intestine, are scarce. Since obtaining high performances in ruminants requires an important supply of bypass protein to complete the rumen synthesised microbial protein, the accurate estimation of rumen degradability and intestinal digestibility of these feeds is very important. The protein from coconut meal not only has a low rumen degradability but also a high intestinal digestibility [6]. In addition, the special fibrous structure of the endosperm of this seed converts this feed into a reference of interest for studying the relations between fibre-bound nitrogen and intestinal digestibility of crude protein (CP).

\section{MATERIALS AND METHODS}

Two groups of three Manchega wethers fitted with rumen cannulas (group 1) or "T" duodenal simple cannulas (group 2) were used, respectively, to estimate the rumen degradability and intestinal digestibility of a sample of coconut meal. Animals were fed at a DM intake level of $40 \mathrm{~g} \cdot \mathrm{kg}^{-1} \mathrm{LW}^{0.75}$ with a 2:1 grass-legume hay to concentrate diet, distributed in two equal meals (at 8:00 and 16:00 h) starting 15 days before the experimental periods. Additional details of this diet have been previously published [4].

Nylon bags with a pore size of $46 \mu \mathrm{m}$ and $11 \times 7 \mathrm{~cm}$ (inner dimensions) were filled with approximately $3 \mathrm{~g}$ (air-dry basis) of coconut meal (grounded to pass a $2 \mathrm{~mm}$ screen) and incubated in the rumen of each animal from group 1 for periods of 2, 4, 8, 16,24 and $48 \mathrm{~h}$ in two series of incubations carried out over different days. After collecting bags from the rumen, they were rinsed under tap water and deep-frozen $\left(-20{ }^{\circ} \mathrm{C}\right)$. After thawing, bags were machine-washed ( 3 times for $5 \mathrm{~min}$ ), dried for $48 \mathrm{~h}$ at $80{ }^{\circ} \mathrm{C}$ in a fan-forced oven and analysed for DM and $\mathrm{N}$. The disappearance of material from the bags with incubation time was described for each animal using the model proposed by McDonald [8] since a lag period was evident for both DM and CP degradation. Effective degradability (ED) was estimated according to Ørskov and McDonald [11] using rumen outflow rate values determined for the diet concentrate labelled with ytterbium as described by González et al. [4]. The intestinal digestibility (ID) of both intact feed and undegraded residues at 24 and $48 \mathrm{~h}$ of rumen incubation was studied using the mobile bag technique. To obtain the rumen-undegraded material, two additional sets of bags were incubated in the rumen of each animal and subjected to the freezing and washing treatments described above. The residues were then freeze-dried, pooled for each incubation time and resulting samples were analysed for DM and N. A total of 6 sub-samples of about $200 \mathrm{mg}$ of coconut meal or of its rumen-undegraded residues were weighed in mobile nylon bags with an approximately round shape $(\varnothing \approx 3 \mathrm{~cm})$. Two bags of each sample were introduced through the duodenal cannula into the small intestine of each wether from group 2 and recovered from the faeces. Bags were then stored, washed and dried as described above and destined intact for nitrogen analysis. Blanks containing a known weight of nylon were used to correct the nitrogen content of nylon material. Additional information about rumen and intestinal incubations or chemical analysis techniques have been previously published [4].

\section{RESULTS}

The chemical composition $\left(\mathrm{g} \cdot \mathrm{kg}^{-1} \mathrm{DM}\right)$ of the used coconut meal was: 932 organic matter (OM), 99.3 ether extract (EE), 569 neutral detergent fibre (NDF), 298 acid detergent fibre (ADF), 89 acid detergent lignin (ADL), and 221 crude protein (CP; $\mathrm{N}$ Kjeldahl $\times 6.25)$. The proportion of $\mathrm{N}$ contained in NDF (NDIN) and ADF (ADIN) was 70.5 and $10.8 \%$, respectively. 
Table I. Rumen degradation and intestinal digestibility of dry matter (DM) and crude protein (CP) of coconut meal.

\begin{tabular}{lcc}
\hline Item & DM & CP \\
\hline Degradation parameters & & \\
$\quad$ Lag time $\left(t_{0} ; \mathrm{h}\right)$ & 8.8 & 15.5 \\
$\quad$ Soluble fraction $(a ; \%)$ & 39.4 & 25.8 \\
$\quad$ Potentially degradable fraction $(b ; \%)$ & 54.4 & 55.1 \\
Degradation rate $\left(\mathrm{k}_{d} ; \% \cdot \mathrm{h}^{-1}\right)$ & 2.52 & 4.75 \\
Effective degradability $(\%)$ & 51.0 & 36.5 \\
& & \\
Intestinal digestibility $(\%)$ & $81.6^{\mathrm{a}}$ & 91.7 \\
Original feed & $62.7^{\mathrm{b}}$ & 91.5 \\
Rumen incubated residue $(24 \mathrm{~h})$ & $50.3^{\mathrm{c}}$ & 90.7 \\
Rumen incubated residue $(48 \mathrm{~h})$ & 2.61 & 0.92 \\
s.e.m. & & \\
\hline
\end{tabular}

a, b, c Values in the same column with different superscripts are different at $P<0.05$.

s.e.m. standard error of the mean.

${ }^{1}$ Calculated as $a+\left(b k_{d} e^{-k p t o} /\left(k_{d}+k_{p}\right)\right)$, with $k_{p}$ values of $5.04 \pm 0.31 \% \cdot \mathrm{h}^{-1}$.

The rumen degradation of both DM and CP from coconut meal (Tab. I) was mainly characterised by an important lag time ( 8.8 and $15.5 \mathrm{~h}$, respectively) and low degradation rates ( 2.52 and $4.75 \% \cdot \mathrm{h}^{-1}$, respectively), which were lower than the rumen outflow rate $\left(5.04 \pm 0.31 \% \cdot \mathrm{h}^{-1}\right.$; mean and standard error). Thus, the main part of the potentially degradable fraction disappeared from the rumen by transit and, therefore, ED values were low, particularly for CP. The values of ID of DM diminished with the extent of rumen degradation (from 81.6 to $50.3 \%$ ) whereas those of CP were not affected by the rumen incubation time (91.3\% as mean).

\section{DISCUSSION}

The chemical composition of the tested meal agrees with data reported in various national feed tables $[1,10]$, with the higher EE content corresponding to the expelling meal category. The high proportion of insoluble nitrogen in ADF and especially in NDF solutions is not usual for extracted meals but agrees with the fibrous character of the endosperm of this seed. These results also show that an important fraction of NDF $(27 \%)$ is composed of CP and not of structural carbohydrates.

The ED value obtained for $\mathrm{CP}$ is lower than those of 52 and $42 \%$ reported respectively by Vérité et al. [14] and Van Straalen and Tamminga [13], but this agrees with the mean value (37\%) of 5 samples reported by Madsen and Hvelplund [9]. The present value is also intermediate between the values of 33\% [9] and 43\% [5] measured in vivo for $\mathrm{CP}$ degradability. The high NDIN proportion and the low ED of CP observed should be related in part with heating effects produced during oil extraction, which are higher with the pressure process than with the solvent process. Consequently, the pressure process has a greater influence on the reduction of CP degradability [2, 3]. Results of ID of CP compare closely with previous results obtained with mobile bags $[6,7,13]$. Moreover, the lack of variation of ID values is in agreement with the results obtained by Hvelplund et al. [7]. The steady evolution of the ID of CP with the increase of rumen 
incubation time allows to estimate the effective digestibility as the mean value. Therefore, a content of $58 \%$ of rumen-undegraded digestible CP can be estimated for this sample. On the contrary, this estimation is not possible for DM, as ID values decreased with increased times of rumen exposure as a consequence of the progressive enrichment in fibre of feed particles with the extent of rumen degradation.

The coconut meal tested combined high values of both NDIN proportion $(70.5 \%)$ and ID of CP for the intact feed (91.7\%), which would result in an important disagreement if it is assumed that fibre-bound nitrogen cannot be solubilised by intestinal enzymes. Nevertheless, the insoluble nitrogen in NDF solution may not be linked to the fibre in this feed but only retained in the fibrous stroma of seed endosperm. A similar disagreement, but of less intensity, among the values of NDIN and those of ID of CP for the intact feed was observed in the results obtained by Pereira et al. [12], heating brewer's grains at increased temperatures. Thus, these results indicate that a fraction of NDIN compounds originating from heat should be available in the gut. Therefore, the use of NDIN values to estimate the ID of CP does not seem to be interesting.

\section{ACKNOWLEDGEMENTS}

This work was supported by the C.I.C.Y.T. of Spain (Project No. AGF 98-0842).

\section{REFERENCES}

[1] Andrieu J., Demarquilly C., Sauvant D., Tables of feeds used in France, in: Jarrige R. (Eds.), Ruminant Nutrition: Recommended Allowances and Feed Tables, INRA, Paris, 1990, p. 298.

[2] Broderick G.A., Relative value of solvent and expeller soybeanmeal for lactating dairy cows, J. Dairy Sci. 69 (1986) 2948-2958.
[3] Goetsch A.L., Owens F.N., The effects of commercial + processing method of cottonseed mea on site and extent of digestion in cattle, J. Anim. Sci. 60 (1985) 803-813.

[4] González J., Sánchez L., Alvir M.R., Estimation of intestinal digestibility of undegraded sunflower meal protein from nylon bag measurements. A mathematical model, Reprod. Nutr. Dev. 39 (1999) 607-616.

[5] Hagemeister H., Kaufmann W., Der Einfluss der rationsgestaltung auf die Verfügbarkeit von Protein-N bzw. Aminosäure-N in Darm der Milchkuh, Kieler Mulchwirtschaftliche Forschungsberichte 26 (1974) 199-220.

[6] Hvelplund T., Digestibility of rumen microbial protein and undegraded dietary protein estimated in the small intestine of sheep and by in sacco procedure, Acta Agric. Scand. Suppl. 25 (1985) 132-144.

[7] Hvelplund T., Weisbjerg M.R., Andersen L.S., Estimation of the true digestibility of rumen undegraded dietary protein in the small intestine of ruminants by the mobile bag technique, Acta Agric. Scand. 42 (1992) 34-39.

[8] McDonald I., A revised model for the estimation of protein degradability in the rumen, J. Agric. Sci. (Camb.) 96 (1981) 251-252.

[9] Madsen J., Hvelplund T., Protein degradation in the rumen. A comparison between in vivo, nylon bag, in vitro and buffer measurements, Acta Agric. Scand. 25 (Suppl.) (1985) 103-124

[10] MAFF, UK Tables of nutritive value and chemical composition of feedingstuffs, in: Givens D.I., Moss A.R. (Eds.), ADAS Feed Evaluation Unit, Stratford on Avon, UK, 1990, p. 420.

[11] Ørskov E.R., McDonald I., The estimation of protein degradability in the rumen from incubation measurements weighted according to rate of passage, J. Agric. Sci. (Camb.) 92 (1979) 499-503.

[12] Pereira J.C., Carro M.D., González J., Alvir M.R., Rodríguez C.A., Rumen degradability and intestinal digestibility of brewers' grains as affected by origin and heat treatment and of barley rootlets, Anim. Feed Sci. Technol. 74 (1998) 107-121.

[13] Van Straalen W.M., Tamminga S., Protein degradation of ruminant diets, in: Wiseman J., Cole D.J.A. (Eds.), Feedstuff evaluation, Butterworth, 1990, pp. 55-72.

[14] Vérité T., Chapoutot P., Michalet-Doreau B., Peyraud J.L., Poncet C., Révision du système des protéines digestibles dans l'intestin (PDI), Bull. Tech. CRZV Theix INRA 70 (1987) 19-34. 